\title{
PERANAN KEPOLISIAN DALAM MENANGGULANGI TINDAK PIDANA PUNGUTAN LIAR DI LEMBAGA PENDIDIKAN (STUDI PADA POLRESTA BARELANG)
}

\author{
DELFANI LAIA, PADRISAN JAMBA \\ Unversitas Putera Batam \\ delfani200@gmail.com
}

\begin{abstract}
In the case of extortion ever happened in the city of Batam. The extortion is in the process of Accepting New Students at SMPN 10 Batam City. The indications of $P P D B$ fraud have actually become suspicion in the community, but in law enforcement in the case of extortion is quite complicated because it is designed systematically in such a way that it will be difficult later in the proof process. Obtained evidence in the form of Money, Proof of Acceptance of New Students, and SK. This investigation is in accordance with KUHAP Article 1 Paragraph (19), the investigation which took place at SMPN 10 Batam City was said to be caught red-handed, the suspect was found at that time. The obstacles of the police in this illegal levy are: Lack of information from the public about the crime of illegal levies and is covered up in carrying out illegal levies at schools, thus hampering the police. Efforts that can be made by the police are to appeal to each agency regarding legal sanctions when committing illegal levies and carrying out patterns of prosecution or punishment against illegal levies based on the legal provisions in the prevailing laws and regulations.
\end{abstract}

Keywords: Extortion, Role of The Police, Investigation

Abstrak: Dalam kasus pemerasan pernah terjadi di kota Batam. Pemerasan sedang dalam proses Penerimaan Siswa Baru di SMPN 10 Kota Batam. Indikasi kecurangan PPDB sebenarnya telah menjadi kecurigaan di masyarakat, tetapi dalam penegakan hukum dalam kasus pemerasan cukup rumit karena dirancang secara sistematis sedemikian rupa sehingga nantinya akan sulit dalam proses pembuktian. Diperoleh bukti dalam bentuk Uang, Bukti Penerimaan Mahasiswa Baru, dan SK. Investigasi ini sesuai dengan KUHAP Pasal 1 Ayat (19), investigasi yang berlangsung di SMPN 10 Kota Batam konon tertangkap tangan, tersangka ditemukan saat itu. Hambatan polisi dalam pungutan liar ini adalah: Kurangnya informasi dari masyarakat tentang kejahatan pungutan liar dan ditutup-tutupi dalam melakukan pungutan liar di sekolah, sehingga menghambat polisi. Upaya yang dapat dilakukan oleh polisi adalah untuk mengajukan banding ke masing-masing lembaga mengenai sanksi hukum ketika melakukan pungutan liar dan melakukan pola penuntutan atau hukuman terhadap pungutan ilegal berdasarkan ketentuan hukum dalam undang-undang dan peraturan yang berlaku.

Kata kunci: Pemerasan, Peran Polisi, Investigasi

\section{A. Pendahuluan}

Sebuah kegiatan pungutan tanpa izin pihak yang berwenang termasuk kepada salah satu permasalahan pelanggaran jenis tindak pidana dimata hukum. Dikatakan tindak pidana adalah masuk kekategori pidana korupsi dan secara umum kegiatan tersebut biasa dilakukan oleh pihak yang terkait dengan kedudukan diinstasi pemerintahan sehiangga meereka mempunyai wewenang dibawah kedudukan 
dipemerintahan dan tidak menutup kemungkinan kegiatan tersebut akan terjadi pada masyarakat umu ataupun biasa disebut dengan publik. Kegiatan jenis pelanggaran tersebut dituangkan pada PERPRES No. 87 tahun 2016 yang menjelaskan dan mengatur tentang pembentukan satuan tugas sapu bersih dari pungutan liar yang sudah berjalan dan mewabah dalam kehidupan masyarakat saat ini. Dengan adanya peraturan tersebut diaharapkan dapat meminimalisir terjadi sebuah kegaitan pungutan liar dan kegiatan pungli ini sudah mulai meresahkan masyarakat yang khusunya untuk pedagang. Walaupun kegiatan pungli sudah masuk dalam kasus jenis hukum pidana dan diaturkan pada kitab undang-undang pidana KUHP, tidak satupun ditemukan mengenai tindak pidana pungli atau delik pungli, akan tetapi yang terkandung makna dari undang-undang tersebut yaitu dalam rumusan tindak Pasal 12 Huruf e UndangUndang Nomor 20 Tahun 2001 yang berlandaskan dari pasal 432 KUHP yang dirujuk dalam Pasal 1 ayat (1) huruf c Undang-Undang Nomor 3 Tahun 1971 Tentang Pemberantasan Tindak Pidana Korupsi, dan Pasal 12 Undang-Undang Nomor 31 Tahun 1999 sebagai tindak pidana korupsi, yang kemudian dirumuskan ulang UndangUndang Nomor 20 Tahun 2001 tentang Pemberantasan Tindak Pidana Korupsi.

Dengan berlandaskan dari permasalahan pungutan liar tersebut memiliki 3 dampak yang dikemukakan oleh (Edwira, 2018) yakni dampak yang pertama adalah kegiatan pungutan liar yang dilakukan dapat meresahkan dan memberatkan kehidupan masyaraka. Kedua adalah dimana tindakan pungli yang akan memberikan keresahan bagi suatu instansi dan suatu lembaga dan kegiatan ini akan berdampak terhadap investasi. Alhasil adalah investor yang akan melakukan investasi secara umum di Indonesia akan merasa keberatan atas kegiatan tersebut sehingga mengakibatkan investor tersebut merasa keberatan untuk menanmkan modal usaha di Indonesia dan kemudian dampak ketiga atas kegiatan pungli ini adalah akan pastinya membuat nama sebuah negara ataupun nama sebuah dari menjadi rusak dan tidak membuat nyaman masyarakat yang bergerak dibidang tertentu.

Pelaku pugutan liar pada umumnya hanya menangkap kemudian melepaskan sama sekali tidak mendatangkan manfaat bagi pemberantasannya pemikiran ini hanya dapat dijadikan bahan pemikiran bagi pengambil kebijakan baik ditingkat pusat maupun di tingkat di daerah, sehingga dengan harapan yang penuh tentang kondisi pada masyarakat agar dapat terjadinya kenyamanan, aman, tertib, dan tercapai transparansi. Semua ini tentunya tidak terlepas dari peran juga kepada masyarakat dalam melakukan partisipasi untuk membantu kepolisian dalam menegakan hukum dan melakukan untuk mengungkap aksi-aksi nakal dari pejabat yang menyalahgunakan ataupun memanfaatkan situasi yang terjadi dimasyarakat. Bahwa harapan atas kesemua ini adalah hal yang sudah sering dan tidak asing lagi bagi telinga masyarakat.

Pungutan liar dalam hal semakin marak aski dilakukan oleh berbagai oknum demi mendapatkan keuntungan semata dan tidak pernah melihat dari jerih payah dibalik seseorang dalam mendapatkan uang tersebut. Dalam kasus praktek pungutan liar ini pernah terjadi di salah satunya kota Batam. Praktek pungutan liar ini terjadi di salah satu sekolah di Sekolah Menengah Pertama Negeri 10 di sei panas. Pada praktek pungli tersebut yaitu dalam proses pada Penerimaan Peserta Didik Baru atau disebut dengan (PPDB) di SMPN 10 Kota Batam ini menjadi perhatian publik nasional. Indikasi dari kecurangan PPDB ini sebenarnya sudah menjadi kecurigaan pada masyarakat namun dalam penegakan hukum pada kasus pungutan liar ini cukuplah rumit dikarenakan dirancang dengan secara sistematis sedemikian rupa sehingga sulit nantinya dalam proses pembuktian. 
Pelaku dari pungli tersebut ada lima orang yang manjadi tersangka dalam kasus pungli penerimaan peserta didik baru, kelimanya adalah Kepala Sekolah Rahip dan Wakilnya Antonius Yudi Novianto, Seorang Guru Honorer Rita dan Staf Admin Mismarita juga berserta Ketua Komite Sekolah Baharudin. Kasus yang terjadi ini pada sabtu malam. Penangkapan Ketua Komite Sekolah Baharudin merupakan pengembangan dari rentetan kasus dari tertangkapnya Rorita, seorang guru honorer dan Staf Admin Mismarita sebagai admin.

Dari hasil penggeledahan dirumah Ketua Komite Sekolah Baharudin bahawa polisi telah menemukan uang tunai senilai ratusan juta dan belasan amplop berisikan uang dengan nama para calon siswa. Bahwa telah diketahui pada pemeriksaan awal jika uang tersebut telah mengalir dibeberapa guru dan pihak sekolah lainnya. Berdasarkan hal tersebut, terdapat permasalahan hukum yang penulis tertarik dalam mengangkat topik tersebut menjadikan sebuah tulisan dalam skripsi ini dengan pengkajian yang lebih mendalam terhadap permasalahan diatas yang berkaitan dengan berbagai macam tindak pidana yang dilakukan oleh ruang lingkup pendidikan di sekitaran masyarakat Kota Batam serta upaya dan peran kepolisian, untuk itu penulis menjadikan sebuah judul dalam bentuk penulisan ini yang berjudul "Peranan Kepolisian Dalam Menanggulangi Tindak Pidana Pungutan Liar Di Lembaga Pendidikan (Studi Pada Polresta Barelang)"

Dengan adanya permasalahan dan kondisi tersbut khususnya maslah pungli, maka maka penulis dengan itu merumuskan permasalahannya Akan melihat dan meninjau peranan pihak berwajib khususnya kepolisian dalam proses menguarangi terjadinya kegiatan tindak pidana pungutan liar di lembaga pendidikan kota Batam danAkan melihat dan meninjau permasalahan yang terjadi dan akan dihadapi oleh pihak berwajib dalam mengurangi tindak pidana pungutan liar di lembaga pendidikan kota Batam. Adapun tujuan dari penelitian ini adalah Untuk mengetahui dan menganalisis peran dari kepolisian Kota Batam dalam menanggulangi tindak pidana pungutan liar di lembaga pendidikan dan Untuk mengetahui dan menganalisis apa saja yang menjadi kendala dalam menanggulangi tindak pidana pungutan liar di lembaga pendidikan.

\section{B. Metodologi Penelitian}

Jenis penelitian yang dilakukan ini adalah sebuah teknik penelitian hukum yang akan memanfaatkan dari kejadian yang nyata empris yaitu diambil dari tingkah laku manusia perilku tersebut secara verbal baik perilaku verbal mealalui wawancara tingkah laku yang nyata mengamati secara lagsung. Penelitian empiris juga digunakan untuk mengamati hasil dari perilaku manusia yang berupa peninggalan fisik maupun arsip. (Mukti Fajar dan Yulianto Achmad, 2010) menurut sifatnya penelitian yang penulis gunakan adalah penelitian deskriptif yaitu Penelitian deskriptif adalah penelitian yang berusaha mendeskripsikan suatu gejala, peristiwa, kejadian yang terjadi saat sekarang. Dalam melakukan penelitian ini, penulis menetapkan lokasi penelitian langsung pada sumbernya data, guna untuk mempersempit penelitian ini atau membatasi ruang lingkup kajian ini hanya pada batas yang penulis tentukan, dan juga agar penulis dapat memfokuskan permasalahan dari penulis lebih rinci, efektif dan relevan. Dalam hal ini penulis pun menetapkan lokasi penelitian yaitu pada penelitian di Kepolisian Kepulauan Riau, khususnya di Polresta Barelang, Batam. 


\section{Hasil dan Pembahasan}

Memerikan kesempatan kepada pihak brwajib dalam melaksanakan tugas Represif Justisil pihak brwajib bekrja jdibawah landaasan azas yang resmi denga nama Criminal Justice Sistem lainnya. Pekrjaan yang akan dilkaukan pihak berwajib ini adalah berbicara tentang langkah dan aturan yang berhak dilakukan oleh pihak berwajib dibawah naungan hukum undang-undang dan azas yang berlaku. Bila terjadi tindak pidana, penyidik melakukan kegiatan berupa: 1) melakukan pencarian sebuah kejadian yang dianggap sebagai tindak kejahatan; 2) Menentukan dapat atau tidaknya dilakukan penyidikan; 3) Mencari serta mengumpulkan bukti; 4) Membuat terang tindak pidana yang terjadi; dan 5) Menemukan tersangka pelaku tindak pidana.(Hamzah, 2014).

Wawancara penulis mendapatkan infomasi langsung dengan Bapak Penyidik di Polresta Barelang yaitu Bapak Jaya Tarigan, mengatakan bahwa di polresta barelanga ini terdiri dari beberapa fungsi dalam bertugas menangani setiap kasusnya, salah satunya terkait dengann fungsi itu adalah Reskrim, yang kepanjangan dari Reserse Kriminal, secara umum fungsi dan kewenanganya yaitu menangani seluruh tindak pidana yang terjadi seperti yang di atur dalam Peraturan Perundang-Undangan, ada beberapa undang-undang yang telah diberikan kewenangan kepada Reskrim ini. Khusus untuk tindak pidana Pungutan Liar ini ditangani oleh dengan Reserse Kriminal oleh unit 2 yaitu Tipikor (Tindak Pidana Korupsi), dari unit 2 inilah yang tidak memandang dari lembaga mana saja dan instansi mana saja sebagai tindak pidana pungutan liar tersebut, jika ada suatu tidak pidana yang terjadi maka di situlah ada kewajiban dalam tugas dan sebagai unit 2 ini melaksanakan tugasnya.(Tarigan, 2020).

Unit dalam reskrim tersebut terdapat penyidik dan penyelidik, penyelidikan adalah serangkaian tindakan untuk mencaridan menemukan suatu peristiwa yang di duga sebagai tindak pidana guna menentukan dapat atau tindakanya dilakukan penyidikan menurut cara yang di atur menurut undang-undang. Yang di maksud dengan reserse dalam organisasi kepolisian adalah tugasnya tentang penerimaan laporan dan pengaturan serta menyetop orang yang dicurigai untuk diperiksa, jadi istilah penyelidikan ini tindakan untuk mendahului penyidikan, adakah tahapan pertama dalam tahapan hukum acara pidana, dengan mencari keberanan. Sedanngkan penyidikan adalah serangakaian tindakan penyidikan dalam hal dan menurut cara yang diatur dalam undang-undang ini untuk mencari serta mengumpulkan bukti yang dengan bukti itu membuat terang tentang tindak pidana yang terjadidan guna menemukan tersangkanya.(Hamzah, 2014).

Proses dari penyelidikan pada kasus SMPN 10 Kota Batam dikarenakan berhubungan dengan Pungutan Liar maka diberikan kewenangan khusus ke Reskrim Khusus pada Unit 2 untuk kegiatan penyelidikan, rangkaian penyelidikan tersebut didasari: 1) Adanya informasi dari masyarakat tentang pungutan liar di SMPN 10 Kota Batam; dan 2) Didapatnya informasi secara langsung oleh penyelidik tentang adanya peritiwa pidana pungutan liar tersebut.(Tarigan, 2020). Berdasarkan dari wawancara penulis mengenai keterangan langsung yang penulis dapatkan yaitu berawal dari bulan Juni pada tepatnnya calon penerimaan siswa baru, karena adanya kegiatan penerimaan siswa baru tersebut, maka sesuai dengan kewenangan dari tugas kepolisian tersebut dengan mencari tahu informasi langsung ke tempat mengenai apakah adanya dugaan atau kegiatan yang dilakukan atau perbuatan kepada calon siswa baru dengan memintakan sejumlah uang kepada orang tua atau wali murid.

Tim Saber Pungli melakukan penyelidikan dengan cara mendatangi kerumah guru yang diduga melakukan tindak pidana ternyata dirumah tersebut kedapatan ada E-ISSN: 2657-0300 Lembaga Penelitian dan Penerbitan Hasil Penelitian Ensiklopedia 
ditemukan orang tua atau wali murid yang berniat mendaftarkan anaknya di SMP 10 Kota Batam. Di SMPN 10 itu sendiri dari bapak Tarigan mengatakan bahwa ini adalah delik yang terjadi adalah delik murni, delik laporan adalah pemberitahuan seseorang karena hak atau kewajibannya berdasarakan undang-undang tentang telah, sedang, atau diduga akan terjadinya peritiwa pidana, sedangkan delik aduan adalah pemberitahuan disertai permintaan pihak yang berkepentingan kepada pejabat berwenang untuk menindak hukum seseorang yang melakukan tindak pidana aduan yang merugikannya. Jadi setiap orang dapat melaporkan suatu kejadian, tetapi pengaduan hanya dapat diajukan oleh orang-orang yang berhak mengajukannya.(Hamzah, 2014).

Berkaitan dengan permasalahan yang terjadi di SMPN 10 Kota Batam bahwa kasus tersebut merupakan kasus yang dilakukan dengan didapatkannya informasi dari masyarakat mengenai adanya pungutan liar, oleh karena itu penyidik mencari tahu tentang adanya peristiwa pidana pungutan liar di SMPN 10 tersebut sehingga peran dari kepolisian akan hal-hal yang meresahkan tersebut, maka dari itu sesuai dengan perannya kepolisian langsung mendatangi langsung ke rumah seorang guru yang di duga melakukan pungutan liar kepada orang tua atau wali murid dan ternyata ditemukan orang tua yang berniat mendaftarkan anaknya didalam rumah guru tersebut. Setelah kejadian itu di duga keras sebagai pendukung atau untuk memperkuat dugaan kepolisian yaitu suatu peristiwa pidana dan di dapatkanlah barang bukti berupa uang, bukti penerimaan siswa baru, dan SK. Hal ini sesuai dengan pada ketentuan KUHAP Pasal 1 Ayat (19) tentang tertangkap tangan, oleh karena itu dalam hal penyelidikan tersebut bahwa tersangka kedapatan pada saat itu juga.

Berkaitan dengan peran kepolisian Polresta Barelang Kota Batam yang penulis dapatkan data diatas sesuia dengan sebagaimana penegak hukum itu sendiri yang dikatan oleh soejono soekanto memelihara, menciptakan dan mempertahankan kedamaian dalam pergaulan hidup, hal yang atau kegiatan yang dilakukan dalam memelihara, menciptakan dan mempertahankan tersebut sudah tepat dilakukan oleh fungsi, tugas dan kewenangan dari Reskrim Unit II yaitu mengenai Tipikor (Tindak Pidana Korupsi) yang sejalan dengan kasus pungutan liar yang dilakukan di lembaga pendidikan Kota Batam. Sehingga terciptalah rasa aman sesuian dengan visi dan misi Kepolisian Republik Indonesia untuk mendaftar calon siswa baru dengan tidak ada lagi pungutan liar sebagai bentuk tindakan nyata dari kepolisian untuk melindungi dan mengayomi masyarakat.

Dalam menanggulangi tindak pidana pungutan liar ini peran dan juga pihak kepolisian juga masih sangatlah membutuhkan peran dari masyarakat juga, tidak terlepas dari itu pada saat wawancara penulis sedikit menanyakan apa saja kendala ataupun yang menjadi hambatan kepolisian dalam melakukan tindak pidana pungutan liar ini yaitu: Minim informasi dari masyarakat mengenai kejahatan pungutan liar walaupun nominalnya kecil atau juga besar dan Terkesan di tutup-tutupi dalam melakukan pungutan liar yang ada disekolah sehingga menghambat juga menjadi kendala dari pihak kepolisian. Upaya yang bisa dilakukan pihak kepolisian dalam menanggulangi aksi pungutan liar diwilayah Kota Batam maka pihak kepolisian yaitu memberikan himbauan kepada setiap instansi mengenai sanksi hukum apabila melakukan kejahatan pungutan liar dan melakukan pola-pola penindakan atau penghukuman terhadap para pelaku pungutan liar berdasarkan ketentuan hukum dalam Peraturan Perundang-Undangan yang berlaku. 


\section{Penutup}

Proses dari penyelidikan pada kasus SMPN 10 Kota Batam berhubungan dengan Tindak Pidana Pungutan Liar maka diberikanlah kewenangan khusus ke Reskrim Khusus pada Unit 2 untuk kegiatan penyelidikan, sesuai dengan kewenangan dari tugas kepolisian tersebut, dengan itu pihak kepolisian berperan mencari tahu informasi langsung ke tempat mengenai apakah adanya dugaan atau kegiatan yang dilakukan atau perbuatan kepada calon siswa baru dengan memintakan sejumlah uang kepada orang tua atau wali murid benar. Dengan itu, sebagai peranannya tim kepolisian bersamaan dengan unit Tim Saber Pungli melakukan penyelidikan dengan cara mendatangi kerumah guru yang diduga melakukan tindak pidana pungutan liar. Untuk memperkuat dugaan kepolisian yaitu di dapatkanlah barang bukti berupa Uang, Bukti Penerimaan Siswa Baru, dan SK. Hal ini sesuai dengan pada ketentuan KUHAP Pasal 1 Ayat (19) tentang tertangkap tangan, oleh karena itu, penyelidikan yang terjadi di SMPN 10 Kota Batam tersebut dapat dikatakan dengan tertangkap tangan, tersangka kedapatan pada saat itu juga. Dalam menanggulangi tindak pidana pungutan liar ini peran dan juga pihak kepolisian juga masih sangatlah membutuhkan peran dari masyarakat juga, tidak terlepas dari itu pada saat wawancara penulis sedikit menanyakan apa saja kendala ataupun yang menjadi hambatan kepolisian dalam melakukan tindak pidana pungutan liar ini yaitu: Minim informasi dari masyarakat mengenai kejahatan pungutan liar walaupun nominalnya kecil atau juga besar dan Terkesan di tutup-tutupi dalam melakukan pungutan liar yang ada disekolah sehingga menghambat juga menjadi kendala dari pihak kepolisian. Upaya yang bisa dilakukan pihak kepolisian dalam menanggulangi aksi pungutan liar diwilayah Kota Batam maka pihak kepolisian yaitu memberikan himbauan kepada setiap instansi mengenai sanksi hukum apabila melakukan kejahatan pungutan liar dan melakukan pola-pola penindakan atau penghukuman terhadap para pelaku pungutan liar berdasarkan ketentuan hukum dalam Peraturan Perundang-Undangan yang berlaku.

\section{Daftar Pustaka}

Adami Chazawi. (2002). Pelajaran Hukum Pidana (Stelsel Tindak Pidana, Teori-Teori Pemidanaan \& Batas Berlakunya Hukum Pidana). Jakarta: Raja Grafindo Persada.

Ali, Z. (2015). Metode Penelitian Hukum. Jakarta: Sinar Grafika.

Aminanto. (2017). Politik Hukum Pidana. Jember: Jember Katamedia.

Barda Nawawi Arief. (2002). Kebijakan Hukum Pidana. Bandung: PT. Citra Aditya Bakti.

BatamNews. (2018). Sosok Kepala Sekolah SMPN 10 Tersangka OTT Di Mata Para Siswa. BatamNews.

Dellyana, S. (1988). Konsep Penegakan Hukum. Yogyakarta: Liberty.

Edwira, M. R. (2018). Upaya Penanggulangan Tindak Pidana Pungutan Liar Oleh Satuan Tugas Sapu Bersih Pungutan Liar (Saber Pungli) (Studi Kasus di Wilayah Hukum Bandar Lampung). Jurnal Skripsi. Retrieved from https://jurnal.fh.unila.ac.id/index.php/pidana/article/download/1119/942

Farouk Muhammad. (2003). Menuju Reformasi Polri. Jakarta: Restu Agung.

H. Moh Hatta. (2010). Kebijakan Politik Kriminal Penegakan Hukum Dalam Rangka Penanggulangan Kejahatan. Yogyakarta: Pustaka Pelajar.

Hamzah, A. (2001). Bunga Rampai Hukum Pidana dan Acara Pidana. jakarta: Ghalia Indonesia.

Hamzah, A. (2014). Hukum Acara Pidana Indonesia (Kedua). Jakarta: sinar grafika.

E-ISSN: 2657-0300 Lembaga Penelitian dan Penerbitan Hasil Penelitian Ensiklopedia 
Harun M.Husen. (1990). Kejahatan dan Penegakan Hukum Di Indonesia. Jakarta: Rineka Cipta.

Hutapea, J. A. (2016). Perbuatan Pungutan Liar (Pungli) Sebagai Tindak Pidana Korupsi (Analisis Pasal 2 Ayat (1) Dan Pasal 3 Uu. Ri Nomor 31 Tahun 1999 Tentang Pemberantasan Tindak Pidana Korupsi Sebagaimana Telah Diubah Dan Ditambah Dalam Uu. Ri Nomor 20 Tahun 2001). Jurnal Nestor Magister Hukum, l(1).

Kumendong, W. J. (2017). Kajian Hukum Tentang Satuan Tugas Sapu Bersih Pungutan Liar Menurut Peraturan Presiden Republik Indonesia Nomor 87 Tahun 2016. Lex Privatum, Vol. V.

Kurnianingrum, T. P. (2016). Pembentukan Satuan Tugas Sapu Bersih Pungutan Liar.

Lijan Poltak Sinambela. (2006). Reformasi Pelayanan Publik: Teori, Kebijakan dan Implermentasi. Jakarta: Sinar Grafika Offset.

Malau, P. (2019). Analisis Juridis Status Kewarganegaraan Atas Sikap Kontradiktif Terhadap Ideologi Negara Dalam Perspektif Kebebasan Mengeluarkan Pendapat. Jurnal Cahaya Keadilan, 7(1).

Masriani, Y. T. (2004). Pengantar Hukum Indonesia. Jakarta: sinar grafika.

Mien Rukmini. (2006). Aspek Hukum Pidana dan Kriminologi (sebuah bunga rampai). Bandung: PT Alumni.

Moeljatno. (1993). Asas-asas Hukum Pidana. Surabaya: Putra Harsa.

Moh. Mahfud MD. (1998). Politik Hukum di Indonesia. Jakarta: Pustaka- LP3ES.

Mukti Fajar dan Yulianto Achmad. (2010). Dualisme Penelitian Hukum Empiris \& Normatif. Jakarta: Pustaka Pelajar.

P.A.F. Lamintang. (2013). Dasar-Dasar Hukum Pidana Indonesia. Bandung: PT. Citra Adityta Bakti.

Prasetyo, T. (2013). Hukum Pidana. Jakarta: Rajawali Pers.

Reksodipuro, M. (1997). Kriminologi dan Sistem Peradilan Pidana Kumpulan Karangan Buku Kedua, Pusat Pelayanan Keadilan dan Pengabdian Hukum Lembaga Kriminologi Universitas Indonesia. jakrta: Universitas Indonesia.

Soerjono Soekanto. (2004). Faktor-Faktor Yang Mempengaruhi Penegeakan Hukum (Kelima). Jakarta: Raja Grafindo Persada.

Supandriyo. (2019). Asas Kebebasan Hakim Dalam Penjatuhan Pidana. Yogyakarta: Arti Bumi Intaran.

Svinarky, I. (2016). Pemberantasan Tindak Pidana Korupsi Terhadap Pungutan Liar (Pungli). Cahaya Keadilan, 4(2).

Tarigan, J. (2020). No Title. Polresta Barelang: Penyidik Tipikor Unit 2.

Ukas Ibrahim. (2015). Analisis Yuridis Pemahaman Ultitarisme Etika dan Profesi Hukum. Jurnal Cahaya Keadilan, 3(2).

Vita Nurul Fathya. (2018). Upaya Reformasi Birokrasi Melalui Area Perubahan Mental Aparatur Untuk Memberantas Praktik Pungli Yang Dilakukan Oleh PNS. Jurnal Ilmu Pemerintahan, 4(1). Retrieved from http://jurnal.unpad.ac.id/cosmogov/article/view/14462

Wahyu Ramadhani. (2017). Penegakon Hukum Dalam Menanggulangi Pungutan Liar Terhadap Pelayanan Publik. Jurnal Hukum Samudra Keadilan, 12(2). 